\title{
Dr James Barry (I789-|865): the Edinburgh years
}

\author{
HM du Preez \\ Consultant Urological Surgeon (Retired)
}

\begin{abstract}
Dr James Barry, a surgeon in the British Army from 1813 until his retirement in 1859, became famous after his death following the revelation that he was in fact a woman who had masqueraded as a man for no less than 56 years. This paper reviews Margaret Bulkley's student years at the University of Edinburgh from the time of her adoption of the identity of the youth calling himself James Barry. The deception was perpetrated in order to obtain a medical degree and the three year MD curriculum was completed without discovery. Few facts are known about these years (1809-1812) and the work of Lisa Rosner has been invaluable as a source of prosopographical information to apply to our knowledge of James Barry's experiences during his time at Edinburgh. Contemporary letters and an Army document also assist in developing this unique and extraordinary story, revealing much that was previously unknown as well as some data, which in earlier work were incorrectly reported.
\end{abstract}

KEYWORDS Dr James Barry, medical history, Edinburgh medical faculty nineteenth century, British Army, female-to-male transgenderism DECLARATIONS OF INTERESTS No conflicts of interest declared.

\begin{abstract}
Correspondence to HM du Preez, The Dower House, 12 Price Drive, Constantia 7806, South Africa
\end{abstract}

\section{Tel +27 2 I 794 I843}

e-mail michael.dupreez@gmail.com
In December 1809, a smooth-faced youth named James Barry matriculated as a medical and literary student at the University of Edinburgh, one of around 900 medical students who attended classes in the city at that time.' There appeared to be nothing strange or remarkable about him, apart from the fact that he might have appeared rather younger than usual, although this in itself would not have aroused too much comment, as medical students registered from the age of about $16^{2}$ and it is not unusual for some 16-year-old youths to appear young for their age. ${ }^{2}$

However there was something exceptional about James Barry, in that he was not a youth, but a young woman already 20 years old. Barry's enrolment as a student in December 1809 marked the start of one of the longest deceptions of gender identity ever recorded, a subterfuge that was to last for 56 years. For the sake of clarity, James Barry will be referred to in the masculine gender throughout this paper.

James Barry assumed his new persona on either 28 or 29 November $1809^{3}$ shortly before he boarded a vessel at Wapping on the Thames, one of the splendid fleet of Leith smacks, bound for Edinburgh. ${ }^{4} \mathrm{He}$ was accompanied on the five day voyage by his mother, Mrs Bulkley, whom he subsequently referred to as his aunt. ${ }^{5}$ Matriculation represented the beginning of the academic year and in the case of this new student, a three year curriculum at Edinburgh, arguably the finest medical school in Britain, and one of the most highly regarded in the world at that time. This particular period in the long life of Dr Barry is examined in this article.

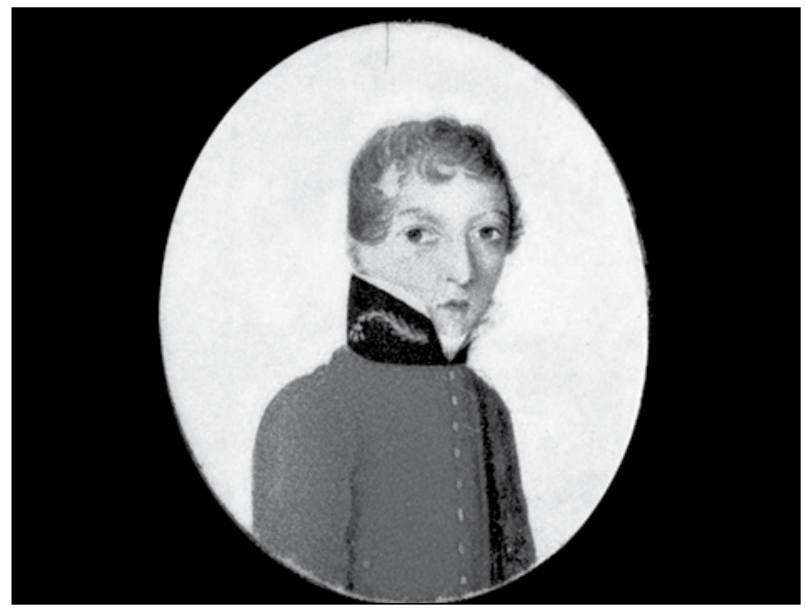

FIGURE | Dr James Barry (1789-1865). Painted at Plymouth c. 1813-1816. Artist unknown. Miniature on ivory. Archive of Dr James Barry Munnik, Cape Town, South Africa.

\section{A DECEPTION IS ARRANGED}

How did this extraordinary deception take place? The story is so unusual that, as the Dublin broadsheet Saunders's News-Letter and Daily Advertiser later stated '... I doubt whether even Miss Braddon herself would have ventured to make use of it in fiction.' (Miss ME Braddon was a popular writer of romantic fiction in the midnineteenth century.)

James Barry was born Margaret Ann Bulkley in Cork in 1789,' the daughter of Jeremiah Bulkley and his wife Mary Anne (née Barry). The Bulkleys ran a successful grocery business at Merchant's Quay, Cork and given the 
location of their home and business, much of it probably involved supplying victuals to the maritime trade. Margaret's brother, John Bulkley was an ineffectual young man upon whom much of the family's money had been lavished to provide him with a good education, followed by an expensive apprenticeship to a Dublin attorney. In I 803 John married above his station in the social scale, which involved considerable additional outlay ${ }^{8}$ which ultimately bankrupted the family. Jeremiah Bulkley was sent to Dublin's Marshalsea prison and a family deposition records that Mary Anne and her daughter Margaret Ann '...now reside in Cork aforesaid in very indigent Circumstances."

A woman of some determination, Mary Anne approached her eldest brother for assistance, seeking advice rather than money. James Barry (I74I-1806) was a Londonbased artist of considerable ability, although appearing to be rewarded with little professional success. A man with a particularly difficult personality, ${ }^{10}$ he held the dubious distinction of being the only academician (until quite recently) to be expelled from the Royal Academy, in his case for a variety of complex charges, allegations, insults and quarrels involving other academicians." Despite writing two letters and visiting London, Mary Anne received no help from her brother. However in 1806 the artist died unexpectedly, leaving assets to his family of more value than would have been suspected from his style of living. ${ }^{3}$ An arguably greater legacy was the personal interest that some of his influential friends were later to take in the affairs of his sister and niece.

\section{THE BENEFACTORS}

Among the close circle of friends of the artist were four men who now assumed great importance in Margaret Ann's life. Dr Edward Fryer, scholar and personal physician to the Duke of Sussex became her personal tutor; Daniel Reardon, the family solicitor, managed the funds accruing after Barry's death, money which paid for Margaret Ann's education. Mrs Bulkley's main concern for her daughter was always that Margaret should have an education '...to put her in a way to get Decent Bread for herself...'. ${ }^{2}$ The third member of this circle was the Venezuelan General Francisco Miranda, soldier, statesman, revolutionary, voluptuary and bibliophile among a host of other qualities. His extensive library was to be important to young Margaret, as it was in the lives of many South American exiles studying in London at that time (personal communication, Mayke De Freitas Santos, April 2012). During a visit to London, Miranda found in Margaret the promise of an intellect more suited to a profession than to the life of a governess, her likely future. It seems certain that it was he who suggested a medical education. The last member of this influential group of benefactors was David Steuart [sic] Erskine, I Ith Earl of Buchan. Lord Buchan was a founder of the Society of Antiquaries of Scotland and as a patron of the arts, took an interest in both the work and the welfare of the, by then, James Barry. Buchan, well known and well-connected in Edinburgh was now able to give much practical support to Barry during his student days in Edinburgh - as well as indicating quite clearly that '... he means to go by invitation of General Miranda to the Caracas.' ${ }^{\prime 3}$ This statement strongly suggests that it was at the General's suggestion that the young Barry became a doctor in order to join his renewed revolutionary efforts in Venezuela. Doctors would be needed during the coming revolution. This revolution failed, however, and James Barry never joined the effort.

At that time women were not admitted to any medical school in Britain. It was not until 1865, the year of Dr Barry's death, that Elizabeth Garrett became the first female to qualify as a doctor in Britain. In order to fulfil Miranda's plan, it was therefore necessary for Margaret to assume the persona and dress of a young man, which she did with great success. ${ }^{14}$ The actual date of Margaret's transformation into James Barry can be stated to within a day or so - Wednesday 29 or Thursday 30 November, 1809. ${ }^{14}$ James and his mother arrived at Leith on the following Monday or Tuesday, 4 or 5 December 1809, just a month after the start of the Winter Session at the University. ${ }^{5}$

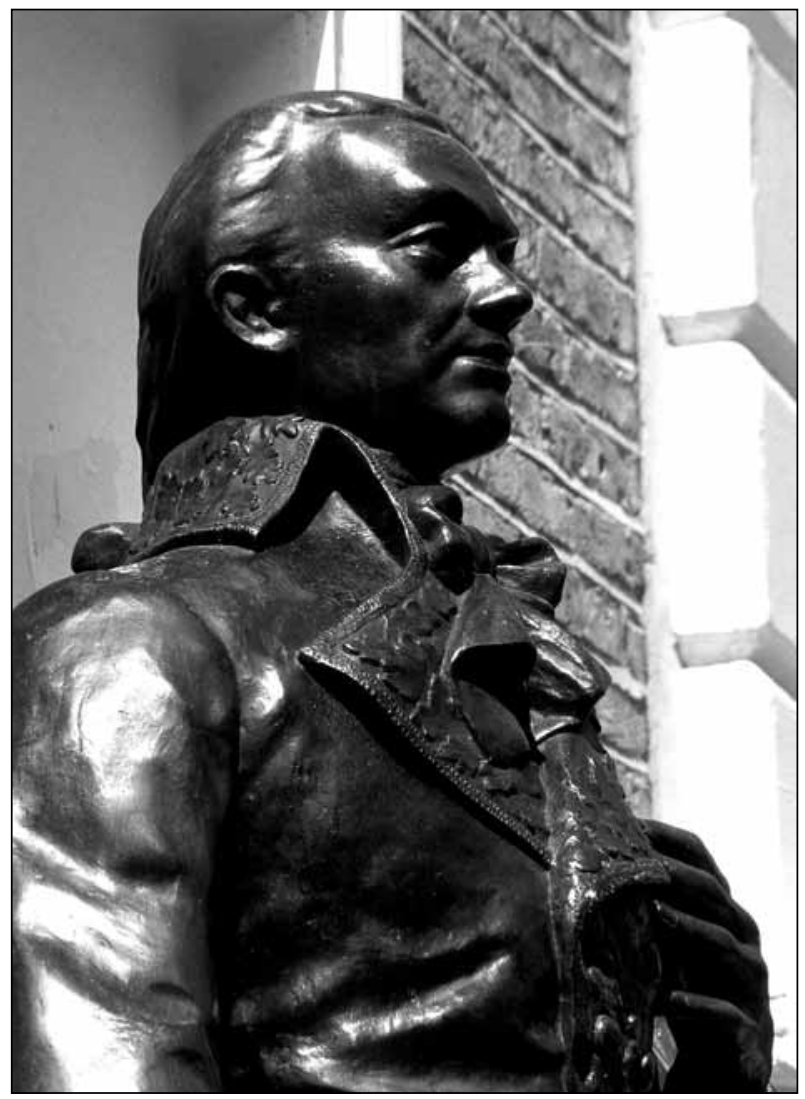

FIGURE 2 Statue of Francisco de Miranda (1750-1816), located on the western end of Grafton Way, London. Image courtesy of the author. 


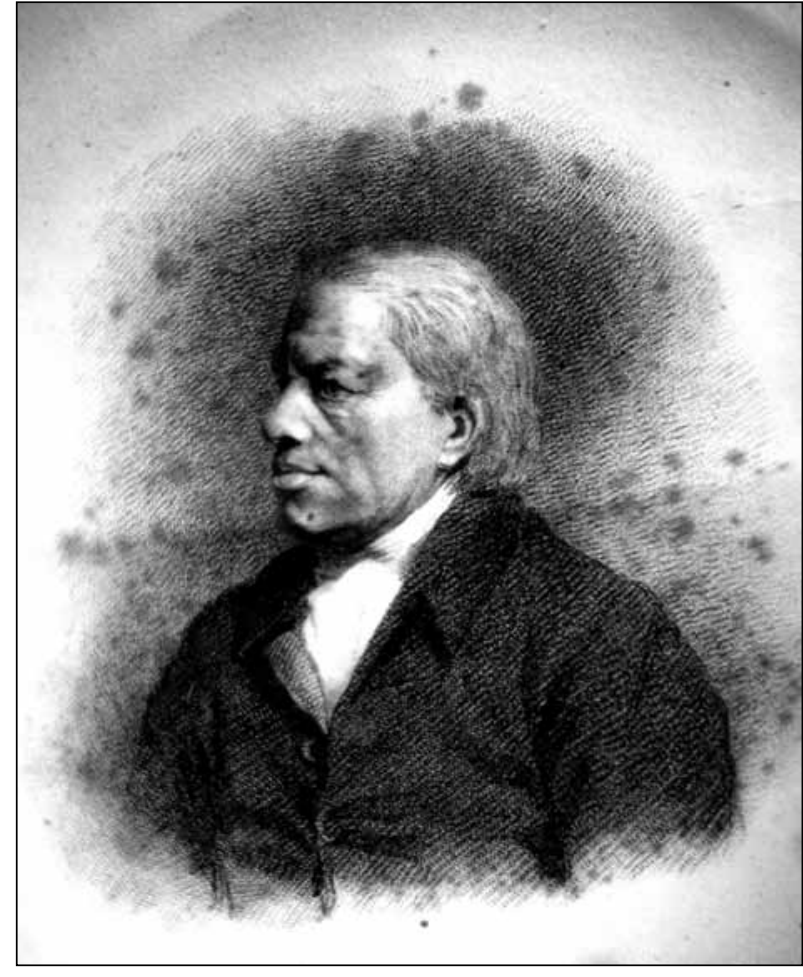

FIGURE 3 James Barry [174|-|806] the Artist by William Evans (from a life mask) 1806. Frontispiece to The Works of James Barry (1809) by Edward Fryer.

\section{MEDICAL TEACHING IN EDINBURGH}

Although James Barry's signature in the Edinburgh University Matriculation Album for $1809^{15}$ was a late entry, it was by no means the last among the names beginning with the letter $B$. June Rose, researching her biography of Barry, found in one of the 1810 Class Registers the annotation 'Known by Lord Buchan, nephew of Mr. B. painter. ${ }^{16}$ The signing of the Album and payment of half a crown (earmarked for the purchase of medical books), usually took place with a certain amount of ceremony in the University Library and was attended by the Principal. At the same time, Barry would have informed the clerk which courses he intended to take during this first year. In his letters to Daniel Reardon ${ }^{17}$ and General Miranda ${ }^{18}$ he states that he had signed up for Chemistry (Dr Hope), Anatomy and Surgery (Professor Alexander Monro tertius), Natural Philosophy and the second Greek course. These details are confirmed by Barry's later entry in his Return of the Services and Professional Education to the Director General of the Army Medical Department, Sir James McGrigor. ${ }^{19}$ This source also states that other courses were added to the four above - Mr Fyfe's Dissection classes and Barclay and Murray's private lectures in Anatomy and Surgery. In the letters to Reardon and Miranda Barry also enthusiastically records that he had been introduced to Lord Buchan, as well as to his professors, mentioning Monro by name. Dr Fryer had once been a student at Edinburgh and he might also have

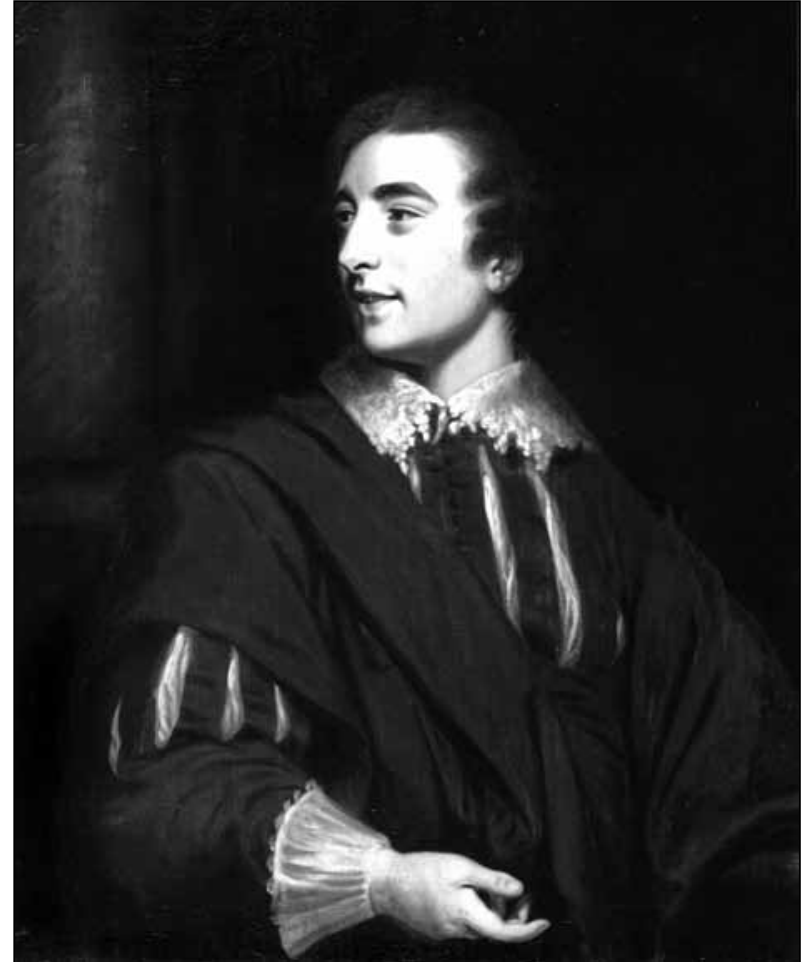

FIGURE 4 David Steuart Erskine (I I th Earl of Buchan) From The University of Edinburgh Fine Art Collection. A copy by an unknown artist after Sir Joshua Reynolds.

furnished a letter of introduction. It seems likely that the well-connected Lord Buchan would have arranged the most useful introductions. It is also of interest to note that Lord Buchan had apparently not been included in the conspiracy about the true identity of the new student; ${ }^{18}$ Mrs Bulkley, Daniel Reardon, Dr Fryer and General Miranda were the only people who were aware of the masquerade.

Most courses cost three guineas and each took place on five days of the week for six months of the Winter term. Anatomy dissections were only conducted during the cold winter months, for obvious reasons and at noon, to make the most of the natural light. The subjects for dissection were supposed to come from judicial executions but this could not always be confirmed. The University anatomists were not the only men seeking bodies for use in teaching as there were other anatomy teachers in the extramural schools in the city, and subjects were in demand.

While students were permitted a certain amount of latitude in the courses they chose, Barry was a particularly diligent student; not only did he attend all the compulsory courses, namely Anatomy and Surgery, Chemistry, Botany, Materia Medica and Pharmacology, Medical Theory and Practice as well as the Clinical Lectures in the Royal Infirmary, ${ }^{20}$ but over the three years of study, he added Midwifery, private Anatomy and Surgery classes, Military Surgery, Medical Jurisprudence, 
Greek II, Natural Philosophy (Physics) and Moral Philosophy (Ethics). He completed two or more courses in eleven of these subjects; three in the cases of Monro tertius' Anatomy and Surgery, as well as his Morbid Anatomy, Dr Hope's Chemistry, Dr Hamilton's Midwifery, Mr Fyfe's Dissection and Barclay and Murray's private lectures. ${ }^{19}$ In addition he held tickets for entry into the Public Dispensary in West Richmond Street, the Lying-in Hospital and a 'perpetual' ticket for the Royal Infirmary.

Unlike many of his contemporaries, Barry remained in Edinburgh during the long summer months, making use of the opportunity to attend two of Rutherford's Botany courses, as well as twelve of his Clinical Lectures, ${ }^{19}$ which were only offered at this time of the year. ${ }^{21} \mathrm{He}$ also attended Clinical Lectures in Medicine and Surgery, Medical Jurisprudence, and Midwifery. ${ }^{19}$

Barry's self-constructed curriculum shows that he studied a total of thirteen subjects, some additionally with different lecturers and extra courses which have not been included in the list as different subjects. According to Ackroyd et al. this number of subjects was exceeded only by one Army medical officer and equalled by one other person in their entire cohort of over 450 army doctors. ${ }^{22}$

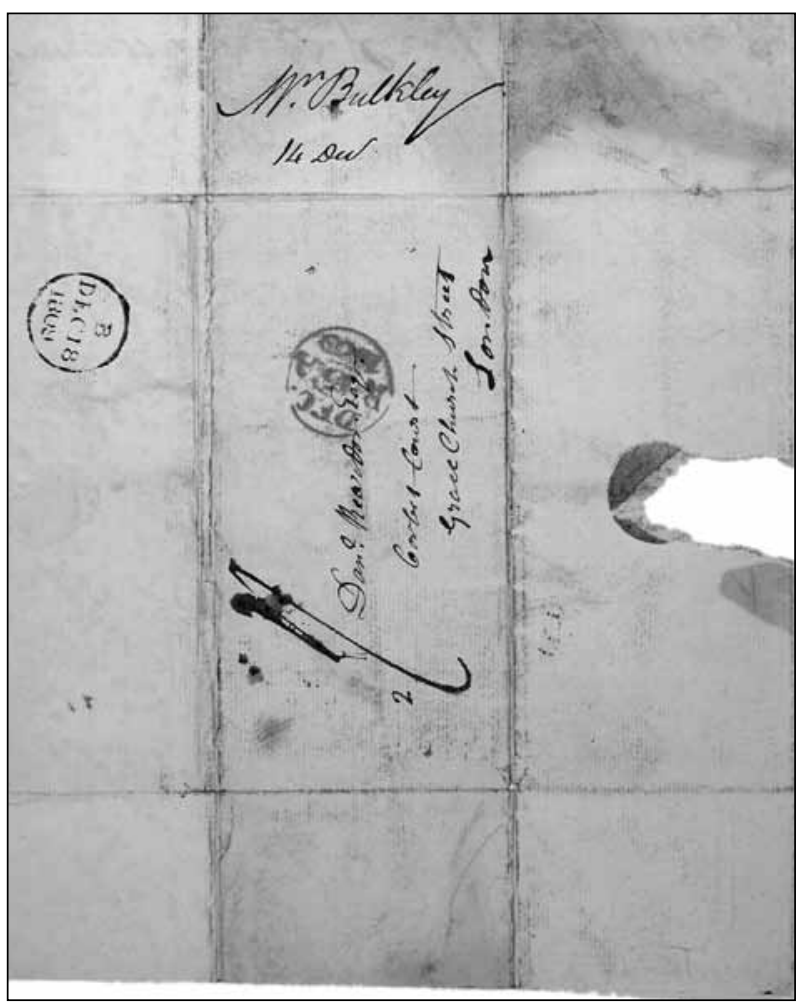

FIGURE 5 Letter from James Barry to Daniel Reardon (14 December 1809). Reardon wrote the name of the sender 'Miss Bulkley' on the cover of the letter, positively identifying her as being James Barry. Image courtesy of The Lewis Walpole Library, Yale University.
This was a golden period at the University of Edinburgh and some of the most celebrated and popular teachers of the time featured on our student's list of classes; men such as James Gregory (Practice of Physic), the popular Thomas Charles Hope (Chemistry), James Hamilton, appropriately described as a Controversialist (Midwifery), John Thomson (Military Medicine), James Home (Pharmacy), Daniel Rutherford (Botany), Andrew Duncan (Theory of Medicine), James Russell (Clinical Surgery) and even Alexander Monro tertius, who was by reputation a terrible lecturer, but the importance of his subjects - Anatomy and Surgery and Morbid Anatomy, made it virtually obligatory to attend his sessions. ${ }^{23}$

\section{JAMES BARRY, MEDICAL STUDENT}

Little is known about the 'scanty particulars' (Janet Carphin's phrase in her 1895 letter to The Lancet) $)^{24}$ of James Barry's day-to-day life at Edinburgh but we do know that he lived in lodgings with his 'aunt' and a number of their addresses feature in the correspondence between Mrs Bulkley and Daniel Reardon. In a letter from Mrs Bulkley to Reardon, dated 14 December $1809,{ }^{5}$ no address is given, simply 'Edinburgh', but she writes 'After a voyage of 5 days we arrived safe at Leith and as soon as possible took lodgings at Edinburgh, where I find everything (almost) cheaper than in London... I only pay $£ 30$ per Ann. for 4 very good rooms and the use of the servant and cooking \&ca...'

James wrote to Reardon on the same day, like his mother not giving an address. However, he did mention '...I have my hands full of delightfull business, \& work from seven o'clock in the morning till two the next. I am become also (no doubt very eligible) a member of the Philopodian Society of Edinburgh and hope in due time to perfect all my plans. It was very usefull for Mrs. Bulkley (my aunt) to have a Gentleman to take care of her on Board Ship and to have one in a strange country - but enough of that..... ${ }^{7}$ Subsequent research revealed no Philopodian Society, leading to the suspicion that this is a humorous reference to the amount of walking between lecture venues that was necessary. Rosner quotes a student, Alexander Lesassier, who wrote in his diary '...nothing but running from Class to Class all day long. ${ }^{25}$ James had an important request for the lawyer '...to ask your leave if at any time any thing should occur to write; if there should be any letters addressed to me from Ireland, you will be so good as to enclose them in your letters to Mrs. B---' And in a postscript: 'I have no friend or acquaintance in London but you \& Dr. Fryer, but I am sure I can rely on your Friendship - please to Direct to James Barry Student, University of Edinburgh.' This was the first written evidence of Barry's plan to cut himself off completely from his past. This letter also holds particular importance in positively identifying Margaret Bulkley and James Barry as one and the same 
person. It was the invariable habit of the recipient, Daniel Reardon, to write in the right hand side of the folded cover (there were no envelopes at that time) the name of the sender of the letter as well as the date it was written.While this particular letter is clearly signed 'Your Truly Obdt. Servt. James Barry', the solicitor had written the name of the sender 'Miss Bulkley'.

The definite identification of Margaret Bulkley and James Barry as the same individual was established in several ways. Pressly compared a September 1808 sample of handwriting (known to be that of Margaret Bulkley) with the writing in James Barry's letter to Daniel Reardon (14 December 1809) and concluded that the two were by the same hand.' Secondly, a professional forensic document analyst compared a set of samples of Margaret Bulkley's handwriting, taken annually between 1804 and 1809 , to the writing in Barry's 1809 letter and pronounced all these to be the work of the same person (personal communication, Alison Reboul, April 2006). Finally, as stated above Daniel Reardon identified the name of the sender as 'Miss Bulkley'.

By Christmas, the pair were established at 6 Lothian Street at Mrs Haggerstone's. Writing to Reardon, Mrs Bulkley stated, 'Your friend, James affairs are going most Happily \& we unite in wishing you and Mrs. R \& family many happy returns of the New Year... N.B it is necessary to mention the Landlady's name, there are so many in one house at Edinburgh...'

On 7 January 1810, Barry wrote a slightly fulsome letter to General Miranda. 'The last day of the year I dined at the Earl Buchan's... I could not help telling his Lordship what a Treasure you possess in London, \& how often you permitted me (Barry's nephew) to partake of it, it is needless to say I mean your very extensive and elegant Library - For my part I am studying and attending the Greek, Natural Philosophy, Chemistry and Anatomy Classes and am honored by the notice of the abovementioned Earl and Dr. Monro, the celebrated Professor of Anatomy.' Following further pleasantries, Barry ended: 'If you should favor me with a line, please to direct to James Barry Student at the University Edinburgh.' Then an asterisk and a very significant piece of information: 'As Lord Buchan nor anyone here knows any thing about Mrs Bulkley's daughter I trust my dear General that neither you nor the Doctor [Fryer] will mention in any of your correspondence any thing about my Cousin's friendship \&ca. for me.' ${ }^{\prime 8}$ It would appear that they remained at Mrs Haggerstone's at least until May 1810 .

Just as James Barry was protecting his secret, so was his mother. In a postscript she writes 'It is not at all necessary to give my address to any of my friends English or Irish, as I do not like to [be] harassed with letters -.26
Buchan used his contacts to expand Barry's circle of mentors and benefactors, in particular to introduce him to the celebrated Edinburgh scholar, editor and biographer, Dr Robert Anderson. As a letter from Lord Buchan to Dr Anderson, of I I Windmill Street, dated 5 July 1810, explains 'I cannot but greatly approve in the expression of yr. Kindness to poor Barry \& yr. Willingness to take him under yr. care as a Boarder when Mrs. Bulkley leaves Scotland. Considering the friendship which subsisted between Barry's Uncle \& myself \& other circumstances I have taken the liberty of recommending him more particularly to yr. Attention as you will see by the two Billets which I send inclosed to yr. care. ${ }^{27}$

It would appear that on Mrs Bulkley's return from London, she and James had moved to Mrs Taylor's at 3 Lothian Street. ${ }^{28}$ The next definite information about Barry's activities comes over a year later, again from Lord Buchan. Writing to Dr Anderson from his country seat at Dryburgh Abbey on 15 October 18II, we learn that 'James Barry... has been here for five weeks past and has employed himself in my Library very busily in useful reading of Books connected with his professional views. He is a well-disposed young man and worthy of yr. notice and advice in his Studies. It will be kind of you and Dr. Irving [Anderson's son-in-law] to look at the Latinity of his Thesis which he tells me he is about to prepare this winter, \& tho he is much younger than is usual to take his Degrees in Medicine and Surgery yet from what I have observed likely to entitle himself to them by his attainments.'13

The last available address for Mrs Bulkley and James Barry is Tennent's Lodgings, 74 Potter Row, the earliest letter from there being dated II February and the last, 28 April 1812. From the February letter, it appears that Mrs Bulkley's health was starting to fail. Significantly, she writes 'We have given up the idea of an annuity for my life ...in consideration of my present state of health ... next July will, please God put an end to all my extraordinary expenses in Edinburgh...' by which we may infer that James is coming to the end of his studies and is preparing for the Final examinations in July. ${ }^{29}$ In the second letter to Reardon dated 28 April, Mrs Bulkley indicates that she wishes to leave for London on 10 May. She wanted to dispose of the Birth of Pandora, a large painting left by her late brother, which did not sell at the auction after his death. She also intended to find lodgings close to Guy's and St Thomas' Hospitals for the final part of James' medical education. ${ }^{30}$

Very little information is available about James Barry's personal life in Edinburgh. Much of what is known comes from a letter to The Lancet written in 1895 by Janet Carphin of Edinburgh. ${ }^{24}$ She had heard about Barry from her friend, Dr Jobson, who had been a student friend of James': 'One of his fellow students was remarkable by 
the persistency with which he avoided his fellow students, and was also laughed at because, in contradistinction to the shooting-coats which all the other students wore, he invariably appeared in a long surtout.' A surtout is an overcoat with long skirts, widely worn in England at the time, perhaps less so in Scotland. ${ }^{31}$ The garment might well have been purchased in London prior to the voyage to Edinburgh. The shooting coat, as far as can be ascertained, was of a similar cut, but with rather shorter skirts, and made of a more 'tweedy' material. ${ }^{32}$ Carphin continued:

However, although Barry kept the other students at a distance, he soon became friendly with Dr. Jobson and invited him to his lodgings, where he introduced him to his mother, with whom he lived. Both Dr. Jobson and Dr. Barry resolved to go into the army, and were together at a depôt where Dr. Jobson was astonished to find that Dr. Barry was afraid to go home by himself through a rather rough part of the town, but asked Dr. Jobson to go with him. Dr. Jobson ... was much disappointed that he could not teach Dr. Barry to box. He never would strike out, but kept his arms over his chest to protect it from blows.

The visit to the Army depôt would, presumably, have taken place after the bad news about General Miranda's imprisonment in 1812 had reached Edinburgh, some weeks after the event. If it is correct that Jobson told Janet Carphin that he had been introduced to Mrs Bulkley as James' 'mother', either he was mistaken, or James himself had inadvertently revealed part of his secret.

Although he was preparing his thesis at the time, Barry worked hard at his other studies. During 1812 , the final year, his courses included Dr Gregory's Practice of Physic, Dr Duncan's Theory of Medicine, Dr Home's Pharmacy Course as well as the Clinical Lectures, Dr Rutherford's Botany Course as well as 12 Clinical Lectures in Botany, Monro's Anatomy and Surgery Course in addition to his second Morbid Anatomy Course and another of Dr Hamilton's Midwifery Courses. He continued with the third of Mr Fyfe's Courses in Dissection and Mr Russell's Clinical Surgery Lectures. At the extramural school he attended the last of Barclay and Murray's courses of private lectures in Anatomy and Surgery and attended the Royal Infirmary and the Lying-in Hospital every day.

The cost of his three years tuition, examination and other fees at Edinburgh has been estimated at $£ 201$ :7:6. That does not include the cost of publishing his thesis, which also had to be borne by the student and of course, board and lodging. Rosner stated '...many students ended up paying around $\mathrm{fl00}$ per year for classes, lodgings, food, books, and so on.' (personal communication, Lisa Rosner, 10 July 2006.) A sum in the region of $£ 2,400$ had come to Mrs Bulkley and Margaret after the death of Barry's artist uncle so the expenses at Edinburgh appeared to be very manageable. ${ }^{3}$

\section{FINAL EXAMINATION}

James Barry was well prepared for the final examination, a complicated four stage procedure. ${ }^{33}$ Three months before the start of the examinations the prospective candidate presented his certificates to the Dean to verify that he had attended the classes. Barry chose to start his campaign in June, so he would have had his appointment with the Dean in March 1812 and paid $£ 10$ (approximately $£ 530$ in 201 I value), ${ }^{34}$ one-sixth of which was paid to each examiner.

The examinations were both written and oral and entirely in Latin, the first being a comparatively informal affair held one evening at the home of one of the professors. A variety of questions were asked - none apparently too difficult - to gauge whether the candidate was likely to succeed in what was to come, or whether his effort should be postponed. A major part of the exercise was the thesis. It was to be written and published by the student, and once the examiners had scrutinised it, the work was defended, in public, in Latin. The thesis was not an original research-based effort, more a dissertation on the chosen subject largely using existing literature. This was the type of activity that James had been carrying out in Lord Buchan's library during that summer of $18 \mathrm{I}$. The subjects selected by Barry's cohort of 58 students were wide and varied, and ranged from $A$ to $V$ - angina to vulneribus. ${ }^{35}$ Barry himself wrote on the subject of femoral hernia - De Merocoele vel Hernia Cruralis. ${ }^{36}$

Femoral hernia (not to be confused with the more common inguinal hernia) was a relatively hot topic at the time. Not only had Monro tertius written about the subject in his $18 \mathrm{II}$ book The Morbid Anatomy of the Human Gullet, Stomach and Intestines ${ }^{37}$ but there was also the recent publication of Sir Astley Cooper's two volume work The Anatomy and Surgical Treatment of Inguinal and Congenital Hernia in 1804 and in 1807, The Anatomy and Surgical Treatment of Crural and Umbilical Hernia. Cooper's experience in treating this less common hernia was extensive, but each of the two volumes was also notable for the fine quality (and expense) of the plates and the size of the elephant folios - each 24 by 18 inches.

The title page of Barry's thesis contains the usual information but two things stand out. First, in a reference to his youthful appearance, Barry somewhat provocatively quoted Menander: 'Do not regard these as the words of a youth but consider whether I reveal the wisdom of a mature individual.' (Translated from the Greek by Emily Kearns, 2003.) This probably refers to 
the fact that Barry had faced the prospect of being barred from sitting the examinations on account of his apparent age. Fortunately Lord Buchan provided a solution in pointing out that the faculty had no rule about the age of an examination candidate at that time. ${ }^{38}$ Barry also described himself as 'Anglus' - an Englishman. This may have been because he by now regarded himself as English, or because he was still rejecting his past, or perhaps it was because there was a degree of antagonism towards Irish students. ${ }^{39}$ While his adopted surname acknowledged his debt to his uncle, the dedications in his thesis also reflected Barry's gratitude towards two of his benefactors, General Miranda and Lord Buchan. Miranda's occupies a full page and begins: 'To Francisco Miranda, the most exalted, the most illustrious General, who from his youth has been winning justice for his most beloved country and for the freedom of the whole world...' By 31 July 1812, Miranda was in Spanish captivity, ${ }^{40}$ ironically this was also the final date on which Barry's work was to be handed to the Dean. Barry's thesis bears the date 24 June. The dedication to Lord Buchan was more restrained: 'Also to that best and most worthy of men, David Steuart Erskine, Earl of Buchan, \&c., \&c., \&c., a magnanimous patron of the arts and humanities, which he himself has most happily cultivated, the author hopes that this dissertation will be both pleasing and acceptable.'

Barry's thesis represents a reasonable account of the state of knowledge of femoral hernia at the time and the surgical anatomy of femoral hernia is particularly well described. Having submitted his thesis, he was now free to concentrate on the final examination. ${ }^{41}$

First came another oral, which took place in the University Library; this generally consisted of a discussion on a medical disorder, often dysentery or pneumonia. Then there was a written examination comprising four questions, set and answered in Latin: first a commentary on one of Hippocrates' aphorisms which often proved challenging, then a general medical question followed by two instructive case histories. Following the successful completion of the oral and the written tests came the defence of the thesis, in public and on the day of graduation. All students were subjected to this ordeal, in a single room and on the same day. Again, Latin was the language used. When everyone had finished, the students waited outside while the Principal asked the professors if they wished him to confer the degree of Doctor of Medicine on the candidates. When this was agreed, the 58 candidates, now gowned, returned, swore the Sponsio Academica and each received his degree "which was conferred by the Principal in the name and by the authority of the University,' at a cost of $£ 25 .{ }^{42}$ Mrs Bulkley's letter to her solicitor would suggest that graduation day was at the end of July $1812,{ }^{43}$ a date confirmed by the Edinburgh University Library (personal communication, Irene Ferguson, II Oct 2006).

\section{EPILOGUE}

Dr James Barry MD left Edinburgh for London, and as far as is known, never returned to Scotland again. On 17 October 1812 he registered at the United Hospitals (Guy's and St Thomas') as a pupil to Mr Whitfield at St Thomas' and signed up for further lectures in Surgery by Astley Cooper and George Cline. ${ }^{44}$ Having decided to join the Army and passing the obligatory examination at the Royal College of Surgeons in London ${ }^{45}$ Barry was recruited. He served with distinction (and more than a little controversy) in no less than eleven different parts of the Empire, until being retired on medical grounds in 1859. ${ }^{46}$ Barry died in London on 25 July 1865. It was only when the mortal remains were being laid out that the truth was discovered and subsequently revealed to an astonished world and an embarrassed Army. ${ }^{6}$

Many aspects of Barry's story have only recently been established beyond doubt: his true identity, origins, age, how his education was funded and why he embarked upon a military career. ${ }^{3}$ After Barry's death, it was asserted by Sophia Bishop, the servant of the London house in which Barry lodged, who laid out the body and who made the extraordinary discovery that the body was not only that of a woman but that there were signs that suggested that she had borne a child 'when very young. ${ }^{37}$ While the latter assertion may be open to doubt, it can now be stated with a degree of confidence that James Barry was a woman and furthermore, was the first woman to graduate in medicine in the United Kingdom.

\section{Acknowledgements}

It is a pleasure to acknowledge the help which I have received from librarians, archivists and experts from around the world, too numerous to mention individually. I would, however like to acknowledge the particular contribution of the art historian William Pressly who in 1985 gave the first clear account of the early background of Margaret Bulkley, which for the first time presented credible proof that Margaret Bulkley and James Barry were one and the same person. 


\section{REFERENCES}

I Rosner L. Medical education in the age of improvement. Edinburgh: Edinburgh University Press; 1991. p. 24.

2 Rosner L. Medical education in the age of improvement. Edinburgh: Edinburgh University Press; 1991. p. 12.

3 du Preez HM. Dr James Barry: the early years revealed. 5 Afr Med J 2008; 98:52-8.

4 W Reid and Son. Reid's Leith and London smack directory. Reid: Edinburgh; 1819.

5 Mary Anne Bulkley. Letter to Daniel Reardon. 1809 Dec 14. Located at: Barry Family Albums, vol ii, Lewis Walpole Library, Farmington, CT, USA.

6 Saunders's News-Letter and Daily Advertiser. 1865 Aug I4. Located at: National Library of Ireland, Dublin.

7 Pressly WL. Portrait of a Cork family: the two James Barrys. Journal of the Cork Historical and Archaeological Society 1985; 90:137-49.

8 John Bulkley. Letter to Jeremiah Bulkley. Circa 1803. Located at: Barry Family Albums, Lewis Walpole Library, Farmington, CT, USA.

9 Deposition by William Edward Penrose, 6 May 1806. Located at: Barry Family Albums, Lewis Walpole Library, Farmington, CT, USA.

10 Pressly WL. The life and art of James Barry. New Haven: Yale University Press; 1981. pp. 38-9; pp. I87-9.

II Pressly WL. The life and art of James Barry. New Haven: Yale University Press; 1981. pp. 139-4I.

12 Mary Anne Bulkley. Letter to James Barry. 1805 Jan I4. Barry Family Albums, Lewis Walpole Library, Farmington, CT, USA.

13 David Steuart Erskine. Letter to Dr Robert Anderson. I8II Oct I5. Located at: National Library of Scotland, Edinburgh, Scotland;Adv. MS.22.4. $13 \mathrm{f} 42$.

14 Daniel Reardon. Statement of account, Mrs and Miss Bulkley: Disbursement. 1809 Nov 28. Located at: Barry Family Albums, Lewis Walpole Library, Farmington, CT, USA.

I5 Folio initial B from matriculation album. Located at: Edinburgh University Library, Edinburgh, Scotland; EUL Da34.

16 Rose J. The perfect gentleman. London: Hutchinson; 1977. p. 17.

17 James Barry. Letter to Daniel Reardon. 809 Dec I4. Located at: Barry Family Albums vol ii, Lewis Walpole Library, Farmington, CT, USA.

I8 James Barry. Letter to General Fransisco Miranda. I8I0 Jan 7. Located at: Miranda Archivo Negociaciones T. xviii f23. Academia Nacional de la Historia, Caracas.

19 Return of the services and professional education of James Barry, M.D. $1824 \mathrm{Apr}$ 7. Located at: National Archives, Kew, England; WO25/3910 f3.

20 Rosner L. Medical education in the age of improvement. Edinburgh: Edinburgh University Press; 1991. p. 63.

2I Bower A. The Edinburgh student's guide: or an account of the classes of the university arranged under the four faculties, with a detail of what is taught in each. Edinburgh:Waugh and Innes; 1822.

22 Ackroyd M, Brockliss L, Moss M et al, editors. Advancing with the Army, medicine, the professions, and social mobility in the British Isles 1790-1850. Oxford: Oxford University Press; 2006. p. 139.

23 Rosner L. Medical education in the age of improvement. Edinburgh: Edinburgh University Press; 1991. p. 48.

24 Carphin J. Letter to the editor. The Lancet 1895; I46:1019-22.

25 Rosner L. Medical education in the age of improvement. Edinburgh: Edinburgh University Press; 1991. p. 61.
26 Mary Anne Bulkley. Letter to Daniel Reardon. I8I0 May II. Located at: Barry Family Albums, vol ii, Lewis Walpole Library, Farmington, CT, USA.

27 David Steuart Erskine. Letter to Dr Robert Anderson. I8I0 Jul 5. Located at: National Library of Scotland, Edinburgh, Scotland; Adv. MS. 22.4.I 3.f38.

28 Mary Anne Bulkley. Letter to Daniel Reardon. I810 Aug 10. Located at: Barry Family Albums, vol ii, Leis Walpole Library, Farmington, CT, USA.

29 Mary Anne Bulkley. Letter to Daniel Reardon. I8I2 Feb II. Located at: Barry Family Albums, vol ii, Lewis Walpole Library, Farmington, CT, USA.

30 Mary Anne Bulkley. Letter to Daniel Reardon. I8I2 Apr 28. Located at: Barry Family Albums, vol ii, Lewis Walpole Library, Farmington, CT, USA.

3I Cunnington CW, Cunnington P. Handbook of English costume in the nineteenth century. 3rd ed. London: Faber and Faber; 1970. p. I09; p. 129.

32 Breward C, Ehrman E, Evans C. The London look: fashion from street to catwalk. New Haven:Yale University Press; 2004. p. I09; p. 129.

33 Rosner L. Medical education in the age of improvement. Edinburgh: Edinburgh University Press; 1991. pp. 72-85.

34 Historical UK inflation and price conversion [Internet]. [cited 2012 jun I5]. Available from: http://safalra.com/other/historical-uk-inflationprice-conversion.com

35 List of the graduates in medicine in the University of Edinburgh from MDCCV to MDCCCLXVI. Edinburgh: Neill and Company; 1867.

36 Barry J. Disputatio medica inauguralis de merocele vel hernia crurali [thesis]. Edinburgh: University of Edinburgh; 1812. Located at: University of Edinburgh Library, Scotland; Att.83.7.15/4.

37 Monro A. The morbid anatomy of the human gullet, stomach and intestines. Edinburgh:Archibald Constable; I8II.

38 Rae I. The strange story of Dr James Barry. London: Longmans, Green and Co; 1958. p. II.

39 Rosner L. Medical education in the age of improvement. Edinburgh: Edinburgh University Press; 1991. p. 39.

40 Harvey R. Liberators: Latin America's struggle for independence. Woodstock, NY:The Overlook Press; 2000. pp. 88-9I.

$4 \mathrm{I}$ Rosner L. Medical education in the age of improvement. Edinburgh: Edinburgh University Press; 1991. p. 8I.

42 Rosner L. Medical education in the age of improvement. Edinburgh: Edinburgh University Press; 1991. p. 85.

43 Rosner L. Medical education in the age of improvement. Edinburgh: Edinburgh University Press; 1991. p. 37.

44 Index of pupils and dressers. St. Thomas' 1723-18/9, Guy's 17681819. Located at: King's College Archives, London;TH/FPI/INI 723$1819 \mathrm{f} 46 ; \mathrm{TH} / \mathrm{FP} 4 / 2 \mathrm{f33}$ and TH/FP7/I f5.

45 The Royal College of Surgeons of England. Register of the Court of Examiners. I8I3 Jul 2. Located at:The Royal College of Surgeons, London, England; 93.

46 Barry, James (cl 792, I795-1865), Surgeon. Statement of Home and Foreign Services. Located at: The National Archives, Kew, England; WO25/3899 f 614

47 McKinnon. Letter to Graham. I865 Aug 24. Located at The National Archives, Kew, England;WOI38/I 